\title{
European Union Oil Import Dependency Risk Analysis
}

\author{
Marko Cirovic*, Dragana Makajic-Nikolic, Natasa Petrovic, \\ Mirko Vujosevic, Marija Kuzmanovic
}

University of Belgrade, Faculty of Organizational Sciences, Belgrade, Serbia

Received: 5 March 2014

Accepted: 9 May 2014

\begin{abstract}
In a world with growing energy demand and increasing energy scarcity, the need for new methods of risk analysis of energy supplies has been emphasized. These methods became even more important for specific energy resources whose future usage is quite questionable, such as oil. This paper will try to examine potential use of one such method for measuring energy security of countries and its dependency on external sources. One method used is failure mode and effect analysis (FMEA), widely used in risk analysis and an inductive modelling approach used to evaluate potential failure modes and their causes. The main goal of FMEA is to prioritize potential risks and lead to actions that will eliminate or reduce the likelihood or effects of their occurrence. Risk evaluation and priority risk numbers were assessed based on expert opinion, using specially created scales developed for the monitored problem. In this paper we try to implement FMEA as a method for quantifying risk of oil shortage for European Union countries and their ability to respond to their growing oil demand and dependency. As a result of this study, ranking these countries by the level of risk they are exposed to will be presented, as well as analysis of the reasons underpinning such rankings.
\end{abstract}

Keywords: energy dependency, risk analysis, FMEA, European Union, environmental protection

\section{Introduction}

According to Europe's Energy Portal website, all oil reserves in the world will be used up on 22 October 2047, at 20:58 hours. According to the calculations of experts of this portal, which monitors the trends of European energy requirements, based on currently known reserves and current world consumption, the reserves of some fossil fuels will be depleted very quickly [1].

European Union countries with more than half a billion inhabitants and a consumption of 13.7 million barrels of oil per day account for $6.8 \%$ of total world oil consumption. Claude Mandil, former executive director of the International Energy Agency in the proposals for the French government before its EU presidency in the first half of

\footnotetext{
*e-mail: marko.cirovic@fon.bg.ac.rs
}

2008 wrote: "Any energy policy, whether national or European, must pursue three principal goals simultaneously: security, combating climate change, and economic growth. There can be no question of choosing any measure that favours one of these goals to the detriment of another" [2].

"Black gold" is one of the most important strategic products in the world today. Oil-producing countries have great power in geopolitical relations, and the control over oil sources is one of the most significant causes of crises in the world. The world market oil price has risen by $600 \%$ since 2000. The assumption is that oil production will reach its peak in the very near future, and by 2050 all of the reserves will be exhausted [3].

EU member states have a large discrepancy in terms of their production capacities and demand for oil. Of the world's 20 largest importers of crude oil, 12 are EU member states. It is clear that these countries rely considerably 
on imports of crude oil and petroleum products, and they depend on oil producers to a great extent, which significantly affects economic, geopolitical, and environmental factors in the EU, as well as the whole world.

Energy dependence is an operational objective of one of the sustainable development indicators, namely the indicator "Climate change and energy." The topic of this paper is the analysis of energy dependence of EU member states from petroleum products by using FMEA to determine the degree of dependency and the consideration of the negative effects that the cessation of the supply of petroleum products can have on each individual member state, as well as the EU as a whole. The FMEA method is an inductive analytical tool for the evaluation of modes and effects of potential failures in subsystems, assemblies, components, or functions. Its main purpose is to identify, quantify, prioritize, and assess risk. Taking into account the population of the countries, a conjoint indicator of their dependence on imported oil and petroleum products, and the annual rate of growth in consumption of petroleum products, it is possible, using the FMEA method, to evaluate the risks to which the EU member states are exposed from the cessation of imports of crude oil and its derivatives.

\section{FMEA Method}

The failure mode and effect analysis (FMEA) method is based on a session of systematic brainstorming aimed at uncovering the failures that might occur in a system or process [4].

FMEA methodology pursues a multitude of aims. It attempts to identify what possible failures may occur in a process and at the same time it pinpoints its sources $[5,6]$.

The main idea of FMEA is to generate a risk priority number (RPN) for each failure mode. The higher the risk number, the more serious the failure could be, and the more important it is that this failure mode be addressed. Some of the basic FMEA terms:

- Occurrence rating. The occurrence rating of a risk is the frequency with which a given risk occurs. Occurrence rating refers to the average likelihood or probability that the risk cause will occur.

- Detection ratings. The detection rating is a measure of the capability of current controls. A detection rating indicates the ability to detect or predict the risk before causing effect.

- Severity ratings. The severity rating is the importance of the risk on end-user requirements. Severity rating is driven by risk effects and criticality and applies only to the effect. Severity rating should be the same each time the same risk effect occurs [7-10].

The ratings of $\mathrm{O}, \mathrm{S}$, and $\mathrm{D}$ can have values ranging from one to 10 based on the universal scales or scales that are formulated for the specific system being analyzed. In our research specific scales were formulated and used.

- Risk priority number (RPN). The risk priority number can be defined as a weighted assessment number used for prioritizing the highest risk items. The RPN focuses efforts on factors that provide opportunities to make the greatest improvement. The RPNs are sorted and actions are recommended for the top issues. Risk assessment should be performed to determine when a corrective action is required. The Risk Priority Number is a mathematical product of the numerical Occurrence $(O)$, Detection $(D)$, and Severity $(S)$ ratings, as shown by Equation 1:

$$
R P N=O \times D \times S
$$

A rule of thumb is to take a serious look at RPNs greater than 125 [8].

When the critical components have been identified and ranked, a concerted effort can be placed on reducing the criticality of the most critical components in the system. Corrective actions should first be directed at the highest ranking concerns and critical items where causes are not well understood. The purpose is to reduce the RPN by applying two types of corrective actions [11]: eliminate or control the cause of the failure; or reduce the ratings of severity, occurrence, and detection.

Those corrective actions will, in many cases, result in changes in the criticality of individual components. For this reason, a FMEA must be accomplished each time a component or subsystem change is executed. The critically ranking list is to be correspondingly revised to reflect changes in component criticality [12]. Therefore, FMEA can be observed as a two-stage technique; the first phase is to identify the potential risks, decide the values for severity, occurrence, and detection, and calculate RPN. In the second phase, recommendations for correct actions should be made, and the RPN needs to be re-calculated after correct actions.

In addition, it should be mentioned that FMEA has been widely applied for risk analysis in the oil and gas industry. For instance, over 80 percent of experts in operator companies, engineering companies, and consultancies in the Norwegian oil and gas industry declared that FMEA was used by their company [13]. However, most of the applications referred to the risk analysis on micro level, such as risk assessment in production and processing of oil [14-18], equipment maintenance [19-21], or safety analysis [22].

\section{Methodology}

The two global oil crises of the 1970s put energy security at the top of the political agenda [23]. Most of the EU countries are very dependent on imports of oil and gas (between $80 \%$ and $100 \%$ ) [24]. Major energy suppliers from Russia and Iran to Venezuela - have been increasingly able and willing to use their energy resources to pursue their strategic and political objectives [25-27]. There for the issue of energy dependency is an issue of political influence as well. Energy security policies are often seen as a part of the strategy for combating climate change [28, 29]. The global demand for oil and gas, rising instability in many producer countries, the rise of state-owned energy champions, and the nearing of the "peak-oil" situation or at least 
the end of "cheap oil" have begun to change the overall balance of power in the relationship between energy producer and consumer states in a way that strengthens the latter [ 30 , 31].

In the following table, a review of EU countries (without the Republic of Croatia as the newest EU member, data are still not fully available) is given by their population numbers and their average oil import dependency. The oil import dependency indicator (OIDI) is calculated as a quotient of net oil import and a sum of total domestic consumption and quantity of oil that each country independently has in its known reserves [32-34]. The same calculation is done for EU as a whole. Values that are indicated represent the average for the period from 1998 to 2010. Equation (2) shows how OIDI is being calculated.

$$
O I D I=\frac{N I}{C+R}
$$

...where:

$N I-\quad$ net oil import

$C-\quad$ current level of oil consumption

$R-\quad$ known oil reserves

This data represents EU countries population numbers and their oil import dependency indicators. This indicator combines data of net oil imports, the quantity of known oil reserves, and the degree to which each country relies on its own oil resources when meeting its oil demand. Data given in Table 1 is the data that was taken into consideration for evaluating severity and occurrence of the failure effect.

For calculating the severity of failure effect ("S" column in Table 3), the number of residing citizens in each county was taken into account. This is due to the fact that the bigger the number of people that are left without oil, the more severe the failure is. For example, Germany will get the highest rank in this category (10), and Malta will get the lowest (1), corresponding to these countries' populations. Fig. 1 depicts the differences in population sizes of these member states.

For evaluating the occurrence of failure effect ("O" column in Table 3), the oil import dependency indicator was taken into account. The higher the value indicator, the higher the dependency on imported oil of the country, and vice versa. The only two countries that have negative value of this indicator are Denmark and the United Kingdom, so we can conclude that their oil demand is heavily covered out of domestic oil reserves. This is why these countries get the lowest rank in this category ( 3 and 5, respectively), while countries such as Spain, Cyprus, and Malta, with indicator values going over 100, get the highest rank (10).

For gaining detection of the failure effect (" $\mathrm{D}$ " column in Table 3), oil consumption per capita was taken into account. The assumption is that the higher consumption per capita is, the more difficult for the country to detect that it is running out of oil. This criterion corresponds to a country's yearly oil consumption growth. Higher detection rating (D) means that it is more probable that a specific country will not detect an oil supply problem in time, hence such a country is more risk prone.
Table 1. Population and oil import dependency indicator of EU member states [23].

\begin{tabular}{|c|c|c|}
\hline $\begin{array}{l}\text { Country } \\
\text { member }\end{array}$ & $\begin{array}{l}\text { Population } \\
\text { (in millions, } \\
\text { January 2014 } \\
\text { estimate) }\end{array}$ & $\begin{array}{l}\text { Oil import dependency } \\
\text { indicator } \\
\text { (net import/ } \\
\text { (consumption }+ \text { known } \\
\text { resources)) }\end{array}$ \\
\hline Malta & 0.42 & 100.63 \\
\hline Cyprus & 0.8 & 100.49 \\
\hline Spain & 47.19 & 100.18 \\
\hline Luxemburg & 0.51 & 99.99 \\
\hline Ireland & 4.48 & 99.95 \\
\hline Sweden & 9.42 & 99.92 \\
\hline Slovenia & 2.05 & 99.79 \\
\hline Greece & 11.33 & 99.69 \\
\hline Belgium & 10.95 & 99.23 \\
\hline Portugal & 10.64 & 99.23 \\
\hline Bulgaria & 7.5 & 98.51 \\
\hline France & 65.08 & 98.22 \\
\hline Latvia & 2.23 & 97.98 \\
\hline Poland & 38.2 & 97.31 \\
\hline Czech Republic & 10.53 & 96.25 \\
\hline Finland & 5.38 & 96.25 \\
\hline Germany & 81.76 & 95.63 \\
\hline Netherlands & 16.66 & 94.54 \\
\hline Italy & 60.63 & 93.05 \\
\hline Slovakia & 5.44 & 92.00 \\
\hline Austria & 8.4 & 91.90 \\
\hline Lithuania & 3.24 & 90.16 \\
\hline Hungary & 9.99 & 78.03 \\
\hline Europe Union & 502.52 & 73.74 \\
\hline Estonia & 1.34 & 72.43 \\
\hline Romania & 21.42 & 42.97 \\
\hline United Kingdom & 62.44 & -21.98 \\
\hline Denmark & 5.56 & -72.19 \\
\hline
\end{tabular}

Oil consumption per capita is the total oil consumed in barrels per day per every 1,000 people (bbl/day per 1,000 people). The discrepancy between the amount of oil produced and/or imported and the amount consumed and/or exported is due to the omission of stock changes, refinery gains, and other complicating factors.

Table 2 shows rating criteria that are used for creating the marks for severity, occurrence, and detection scales. When dealing with energy supply risk, we can note that 
Table 2. Rating criteria for severity, occurrence, and detection.

\begin{tabular}{|c|c|c|c|}
\hline Rating & $\begin{array}{c}\text { Severity } \\
\text { (million } \\
\text { citizens) }\end{array}$ & $\begin{array}{c}\text { Occurrence } \\
\text { (oil import } \\
\text { dependency } \\
\text { indicator) }\end{array}$ & $\begin{array}{c}\text { Detection } \\
\text { (bbl/day per } \\
1.000 \text { people) }\end{array}$ \\
\hline 1 & $0-1$ & $-125--100$ & $0-10$ \\
\hline 2 & $1-4$ & $-100--75$ & $10-20$ \\
\hline 3 & $4-7$ & $-75--50$ & $20-30$ \\
\hline 4 & $7-10$ & $-50--25$ & $30-40$ \\
\hline 5 & $10-15$ & $-25-0$ & $40-50$ \\
\hline 6 & $15-25$ & $0-25$ & $50-60$ \\
\hline 7 & $25-40$ & $25-50$ & $60-70$ \\
\hline 8 & $40-55$ & $50-75$ & $70-80$ \\
\hline 9 & $55-80$ & $75-100$ & $80-90$ \\
\hline 10 & over 80 & $100-125$ & $90-100$ \\
\hline
\end{tabular}

similar scales were formulated in [35], when FMEA was used to evaluate the risk associated with wind turbines, in [36] for risk associated with geothermal power plants, and in [37] when FMEA risk analysis of biomass combustion was done.

\section{Results and Discussion}

Results gained after conducting the analysis on the above-given data and after assigning ranks for all three categories are shown in Table 3, sorted by risk priority numbers (RPN) and presents the central results of our study. The third column shows values of the severity ratings based on population size. The forth column shows values of the occurrence ratings. The fifth column provides values of detection ratings based on oil consumption per capita. Finally, values of the risk priority number (RPN) are displayed in the last column.
From the results that are acquired it can be concluded that the Netherlands, with a calculated RPN value of 378 , is the most subjected to crises in the potential case of oil import disruption. Such a high value of the Netherlands RPN is mostly based on the high value of its occurrence rating (9) because of its high OIDI. The fact that the Netherlands is Europe's second biggest oil importer and is ranked as a No. 6 in the World underpins the argument.

Germany, with its RPN value of 360, and Belgium, with 270 , are quite jeopardized on the same criterion. Germany otherwise is Europe's biggest crude oil importer, and is ranked as the world's fifth oil importer. Another factor contributing to Germany's RPN score is its large population $(\mathrm{S}=10)$, while Belgium's additional contributing factor is its high rate of oil consumption per capita, which makes a potential oil shortage hard to detect $(\mathrm{D}=6)$. It will be interesting to see how German oil consumption will change in upcoming years based on the German Renewable Act (EEG) and how a stronger shift to renewable sources of energy motivated by newly adopted European and German energy policies [38] will develop, regarding that these policies demand abolishment of traditional energy sources and a strong shift toward renewable ones.

The European Union as a whole is ranked at an alarmingly high $6^{\text {th }}$ place, with RPN value of 240 . On the other hand this is not surprising because within its borders the EU has just two countries with significant oil production and with its own oil sources: Denmark and the United Kingdom. More than $50 \%$ of oil that the EU imports comes from Norway and Russia, which makes these countries quite influential on Europe's economic and political streams.

On the other side we have Denmark, Cyprus, and Latvia with RPN values, respectively, of 27, 30, and 36. Denmark is basically completely independent from the rest of the EU when it comes to oil and when we take into account the fact that it has its own oil resources in the North Sea that satisfy this country's population needs. This is why Denmark and the Netherlands, although similar countries (population, size, position), are so different in rankings. Additionally, we can note that Denmark and the Netherlands have different

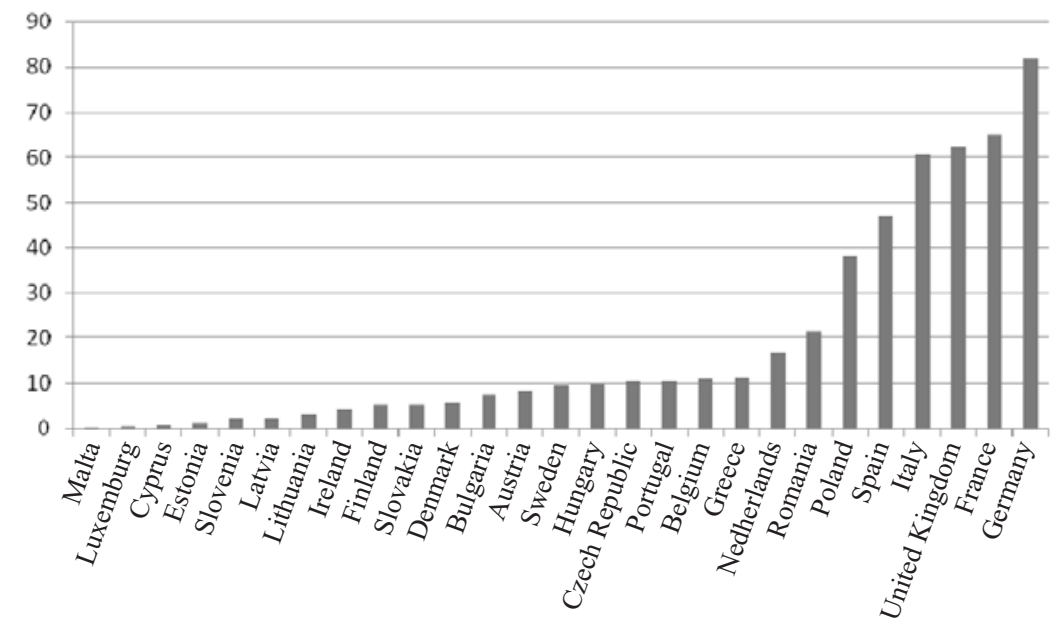

Fig. 1. EU 27 member states by their population size. 
Table 3. Oil dependency of EU counties according to the FMEA method, sorted by RPN.

\begin{tabular}{|c|c|c|c|c|c|}
\hline 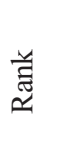 & $\begin{array}{l}\text { 盇 } \\
\text { 巳 }\end{array}$ & 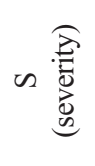 & 0 总 & 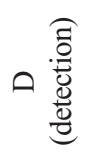 & 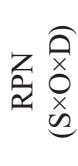 \\
\hline 1. & Netherlands & 6 & 9 & 7 & 378 \\
\hline 2. & Germany & 10 & 9 & 4 & 360 \\
\hline 3. & Belgium & 5 & 9 & 6 & 270 \\
\hline 4. & France & 9 & 9 & 3 & 243 \\
\hline 5. & Italy & 9 & 9 & 3 & 243 \\
\hline 6. & EU & 10 & 8 & 3 & 240 \\
\hline 7. & Spain & 8 & 10 & 3 & 240 \\
\hline 8. & Greece & 5 & 9 & 4 & 180 \\
\hline 9. & Austria & 4 & 9 & 4 & 144 \\
\hline 10. & Sweden & 4 & 9 & 4 & 144 \\
\hline 11. & Portugal & 5 & 9 & 3 & 135 \\
\hline 12. & Poland & 7 & 9 & 2 & 126 \\
\hline 13. & Finland & 3 & 9 & 4 & 96 \\
\hline 14. & UK & 9 & 5 & 2 & 90 \\
\hline 15. & Czech republic & 5 & 9 & 2 & 90 \\
\hline 16. & Ireland & 3 & 9 & 3 & 81 \\
\hline 17. & Luxemburg & 1 & 9 & 9 & 81 \\
\hline 18. & Bulgaria & 4 & 9 & 2 & 72 \\
\hline 19. & Hungary & 4 & 9 & 2 & 72 \\
\hline 20. & Slovakia & 3 & 9 & 2 & 54 \\
\hline 21. & Slovenia & 2 & 9 & 3 & 54 \\
\hline 22. & Malta & 1 & 10 & 5 & 50 \\
\hline 23. & Estonia & 2 & 8 & 3 & 48 \\
\hline 24. & Romania & 6 & 7 & 1 & 42 \\
\hline 25. & Lithuania & 2 & 9 & 2 & 36 \\
\hline 26. & Latvia & 2 & 9 & 2 & 36 \\
\hline 27. & Cyprus & 1 & 10 & 3 & 30 \\
\hline 28. & Denmark & 3 & 3 & 3 & 27 \\
\hline
\end{tabular}

approaches to alternative energy sources [39, 40]. Cyprus, with its modest population of 800,000 people $(S=1)$, comes with the second lowest rank with RPI value of 30, followed by Latvia, mostly due to its low consumption per capita and small population size $(D=2, S=2)$. Additionally, Cyprus made a commitment toward sustainable development and on the use of renewable energy sources (RES) as well as toward UN Agenda 21 in 1992. Agenda 21 is a comprehensive plan of action to be taken globally, nationally, and locally by organizations of the United Nations, governments, and major groups in areas in which humans affect the environment. Cyprus has launched strategies and initiatives in order to increase the RES share in the energy mix beyond the spectacular utilization of solar thermal energy [41].

Fig. 2 shows the comparison of countries' ranking by using just the oil import dependency indicator to more encompassing ranking gained by the FMEA method. Future analysis in the field should include other factors alongside the ones used in this paper as more data become available. This figure demonstrates how relying on just one of the factors can be misleading and misrepresent the potential risks of EU oil security.

\section{Conclusions}

The FMEA method has shown itself to be a possibly useful approach for determining energy dependency of EU countries. Primarily, a further step would be analysis of the Republic of Croatia, the newest EU member and analysis of the oil dependency factors of all other potential EU candidates. Such data would give even more thorough insight into what the future holds.

The analysis pointed to some general facts that are known on the basis of available data: the high energy independence of Denmark and Great Britain, which have their sources of crude oil; the heavy dependency on imported petroleum products of Benelux countries, Spain and Poland; but also the somewhat surprising $6^{\text {th }}$ place (out of 28 on the list) of the European Union as a whole. More than 50 percent of petroleum products that the EU imports comes from Norway and the Russian Federation which, although European countries, are not members of the EU-

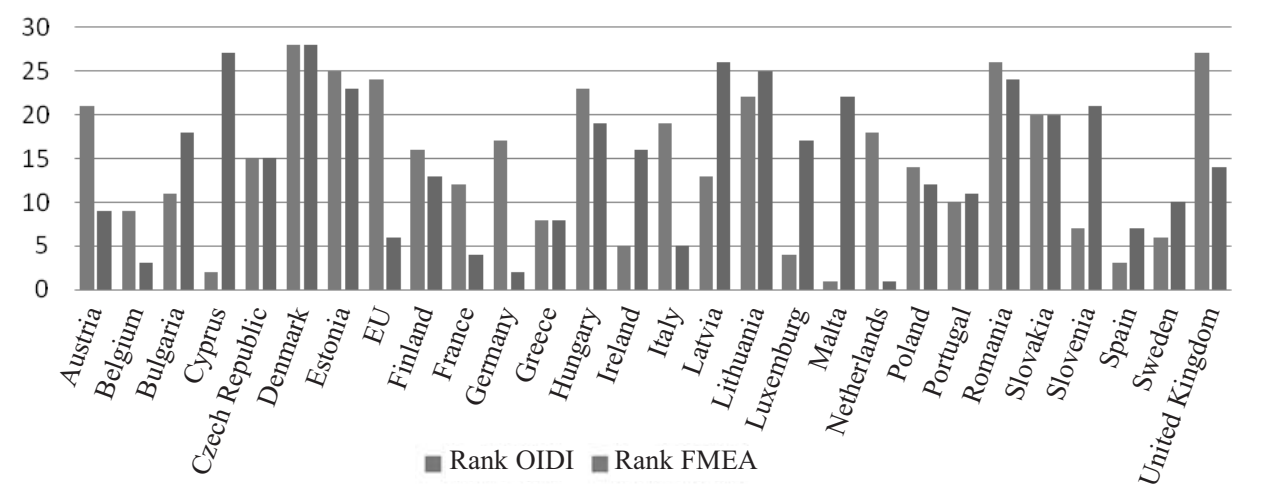

Fig. 2. OIDI and FMEA ranking comparison. 
28, and thus have a major impact on the economic and political developments in the European Union.

Energy dependence on oil is a reality for the European Union and as well for a large part of the rest of the world, and will probably remain so until the last reserves of "black gold" are consumed. This means that EU oil dependency will become an even more significant issue in the upcoming years. One of the potential remedies to the problem could be implementation of practices similar to the ones implemented by other countries highly dependant on oil, such as China, Japan, and the USA. These countries have implemented oil import diversification strategies that have reduced the risk of potential oil shortages [42-44].

As regards limitation of the study, it can be viewed through limitations of the FMEA method. Some of the more obvious ones as the fact that relative importance among $\mathrm{O}, \mathrm{S}$, and $\mathrm{D}$ is not taken into consideration or that different combinations of $\mathrm{O}, \mathrm{S}$, and $\mathrm{D}$ may produce exactly the same value of RPN, but their hidden risk implications may be totally different and that the RPN considers only three risk factors, mainly in terms of safety, that should be addressed in the future [45].

As always, when oil is in question a solution to the problem should be searched in alternatives. Currently humanity is facing a crossroads in it further development. For the last 150 years increases in oil production were always followed by the increase in oil consumption. This period can be called the "oil era," but inevitably EU countries will have to shift their energy dependency to other energy resources.

\section{References}

1. EUROPEAN COMMISSION ENERGY PORTAL. http://www.energy.eu/\# (accessed 20. 12. 2013).

2. FRENCH GOVERNMENT ANNUAL REPORTS. http://www.premier-ministre.gouv.fr/IMG/pdf/081005 Rapport_au_Premier_ministre_final_ENG.pdf (accessed 21. 12. 2013).

3. CENTRAL INTELLIGENCE AGENCY (CIA). Factbook: Lists population, government, military, and economic information for nations recognized by the United States. https://www.cia.gov/library/publications/the-world-factbook/ fields/2241.html\#33 (accessed 20. 12. 2013).

4. CLIFTON J.J. Risk prediction, in Keller A.Z. and Wilson H.C. (Eds.) Disaster prevention, Planning and Limitation Unit, University of Bradford, Bradford, 1990.

5. MCDERMOTT R.E., MIKULAK R.J., BEAUREGARD M.R. The basis of FMEA, Productivity Inc., Portland, OR, 1996.

6. MAKAJIC-NIKOLIC D., JEDNAK S., BENKOVIC S., POZNANIC V. Project finance risk evaluation of the Electric power industry of Serbia, Energy Policy. 39, (10), 6168, 2011.

7. ERICSON II C.A. Hazard analysis technique for system safety. John Wiley \& Sons, 2005.

8. AYYUB B.M. Risk analysis in engineering and economics, Chapman and Hall/CRC, 2003.

9. ALMANNAI B., GREENOUGH R., KAY J. A decision support tool based on QFD and FMEA for the selection of manufacturing automation technologies. Robotics and Computer-Integrated Manufacturing. 24, 501, 2008.

10. VUJOŠEVIC M. Fault tree analysis; view of the basic concept and technique, Tehnika. 38, (11), 1546, 1983.

11. PUENTE J., PINO R., PRIORE P., FUENTE D. A decision support system for applying failure mode and effects analysis, International Journal of Quality \& Reliability Management. 19, (2), 137, 2002.

12. KECECIOGLU D.B. Reliability Engineering Handbook. DEStech Publications, Inc., 1, 2, 2002.

13. ANDERSEN S., MOSTUE B.A. Risk analysis and risk management approaches applied to the petroleum industry and their applicability to IO concepts. Safety Science. 50, 2010, 2012.

14. ROONEY J.J., TURNER J.H., ARENDT J.S. A preliminary hazards analysis of a fluid catalytic cracking unit complex. Journal of Loss Prevention in the Process Industries. 1, (2), 96, 1988.

15. DEEGAN F.J., BURNS D.J. Failure mode and effect analysis of a subsea production system. Inst Marine Engrs Trans. 102, (3), 191, 1990.

16. CHEN H., MOAN T., VERHOEVEN H. Safety of dynamic positioning operations on mobile offshore drilling units. Reliability Engineering \& System Safety. 93, (7), 1072, 2008.

17. HEKMAPATNAH M., SHAHIN A., RAVICHANDRAN N. The application of FMEA in the oil industry in Iran: the case of four litter oil canning process of Sepahan oil company. African Journal of Business Management. 5, 3019, 2011.

18. NABHANI N., JADERI F., SA'IDI E. Risk assessment and risk management of Abadan refinery's sandblasting unit using FMEA method. International Conference on Chemical, Environmental Science and Engineering (ICEEBS'2012), July 28-29, Pattaya, Thailand, 2012.

19. AZADEH A., EBRAHIMIPOUR V., BAVAR P. A pump FMEA approach to improve reliability centered maintenance procedure: the case of centrifugal pumps in onshore industry. Proceedings of the $6^{\text {th }}$ WSEAS International Conference on FLUID MECHANICS (FLUIDS'09). pp. 3845, 2009.

20. AZADEH A., EBRAHIMIPOUR V., BAVAR P. A fuzzy inference system for pump failure diagnosis to improve maintenance process: The case of a petrochemical industry. Expert Systems with Applications. 37, (1), 627, 2010.

21. WANG Y., CHENG G., HU H., WU W. Development of a risk-based maintenance strategy using FMEA for a continuous catalytic reforming plant. Journal of Loss Prevention in the Process Industries. 25, (6), 958, 2012.

22. CATELANI M., CIANI L., LUONGO V. Safety analysis in oil \& gas industry in compliance with standards IEC61508 and IEC61511: Methods and applications. In: IEEE International Instrumentation and Measurement Technology Conference: Instrumentation and Measurement for Life, I2MTC, Minneapolis, USA. pp. 686-690, 2013.

23. HEDENUS F., AZAR C., JOHANSSON D.J.A. Energy security policies in EU-25 - The expected cost of oil supply disruptions. Energy policy 38, (3), 1241, 2010.

24. CHRISTIE E. Oil and gas dependence of EU-15 countries. Verein, Wiener Inst. für Internat. Wirtschaftsvergleiche (WIIW), 2007.

25. JOZI S.A., SAFFARIAN S., SHAFIE M. Environmental risk assessment of a gas power plant exploitation unit using integrated top-eFMEA method. Pol. J. Environ. Stud. 21, (1), 95, 2012 
26. DEUTCH J., SCHLESINGER J.R., VICTOR D.G. National security consequences of US oil dependency. Council on foreign relations. New York, 2006.

27. DIETER H. The Russian dimension and Europe's external energy policy. University of Oxford, 2007.

28. EU-COMMISSION. Directive 2003/30/EC of the European Parliament and of the Council of 8 May 2003 on the promotion of the use of biofuels or other renewable fuels for transport. Official Journal of the European Union. 5, 2003.

29. COHEN A. Europe's Strategic Dependence on Russian Energy. The Heritage Foundation, Backgrounder 2083, 2007.

30. ANDERSEN S.S. EU energy policy: Interest interaction and supranational authority. ARENA, 2000.

31. UMBACH F. Global energy security and the implications for the EU. Energy Policy. 38, (3), 1229, 2010.

32. EUROPEAN UNION COMMISSION detailed statistics on EU and candidate countries.

http://epp.eurostat.ec.europa.eu/statistics_explained/index. php/Consumption_of_energy (accessed $1 \overline{2} .12 .2013$ ).

33. European Commission. A European strategy for sustainable, Competitive and secure energy, Brussels, COM (2006), 105, 2006.

34. European Commission. Energy for the future: renewable sources of energy. White Paper for a Community Strategy and Action Plan, Brussels, COM (97), 599, 1997.

35. ARABIAN-HOSEYNABADI H., ORAEE H., TAVNER P. J. Failure modes and effects analysis (FMEA) for wind turbines. International Journal of Electrical Power \& Energy Systems. 32, (7), 817, 2010.

36. FEILI H. R., AKAR N., LOTFIZADEH H., BAIRAMPOUR M., NASIRI S. Risk analysis of geothermal power plants using Failure Modes and Effects Analysis (FMEA) technique. Energy Conversion and Management. 72, 69, 2013.

37. THIVEL P. X., BULTEL Y., DELPECH F. Risk analysis of a biomass combustion process using MOSAR and FMEA methods. Journal of hazardous materials. 151, (1), 221, 2008.

38. AGNOLUCCI P. Use of economic instruments in the German renewable electricity policy. Energy Policy. 34, (18), 3538, 2006.

39. BOON F. P., DIEPERINK C. Local civil society based renewable energy organisations in the Netherlands: Exploring the factors that stimulate their emergence and development. Energy Policy. 69, 297, 2014.

40. KAMP L. M., SMITS R. E., ANDRIESSE C. D. Notions on learning applied to wind turbine development in the Netherlands and Denmark. Energy policy, 32, (14), 1625, 2004.

41. MAXOUliS C. N., KALOGIROU S. A. Cyprus energy policy: the road to the 2006 world renewable energy congress trophy. Renewable Energy. 33, (3), 355, 2008.

42. YANG Y., LI, J., SUN X., CHEN J. Measuring external oil supply risk: A modified diversification index with country risk and potential oil exports. Energy, 68, 930, 2014.

43. LESBIREL S. H. Diversification and energy security risks: the Japanese case. Japanese Journal of Political Science, 5, (1), 1, 2004.

44. WABIRI NJERI, HAMMED AMUSA. Quantifying South Africa's crude oil import risk: A multi-criteria portfolio model. Economic modelling. 27, (1), 445, 2010.

45. LIU H., LIU L., LIU N. Risk evaluation approaches in failure mode and effects analysis: A literature review. Expert Systems With Applications. 40, (2), 828, 2013. 
